Keywords: Tank Farm

ETP

Characterization

Retention: Permanent

\title{
Report on the Analysis of WAC Samples from Evaporator Overheads for 2011
}

Aaron L. Washington, II

March 2011

Savannah River National Laboratory Savannah River Nuclear Solutions Aiken, SC 29808

Prepared for the U.S. Department of Energy under contract number DE-AC09-08SR22470.

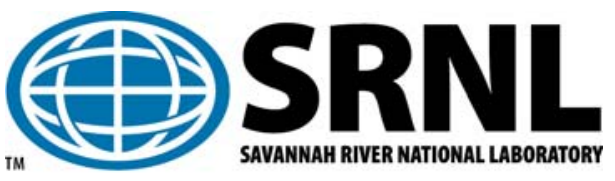




\section{DISCLAIMER}

This work was prepared under an agreement with and funded by the U.S. Government. Neither the U.S. Government or its employees, nor any of its contractors, subcontractors or their employees, makes any express or implied:

1. warranty or assumes any legal liability for the accuracy, completeness, or for the use or results of such use of any information, product, or process disclosed; or

2. representation that such use or results of such use would not infringe privately owned rights; or

3. endorsement or recommendation of any specifically identified commercial product, process, or service.

Any views and opinions of authors expressed in this work do not necessarily state or reflect those of the United States Government, or its contractors, or subcontractors.

\section{Printed in the United States of America}

Prepared for U.S. Department of Energy 


\section{REVIEWS AND APPROVALS}

\section{AUTHORS:}

$\overline{\text { A. L. Washington, II, Advanced Characterization and Processing (ACP) }}$ Date

TECHNICAL REVIEW:

Michael Hay Design Check, Advanced Characterization and Processing (ACP) Date

\section{APPROVAL:}

F.M. Pennebaker, Manager

Date

Advanced Characterization and Processing (ACP)

S.L. Marra, Manager

Date

Environmental \& Chemical Process Technology Research Programs

Tank Farm/ETP Process Engineering Lead 


\section{EXECUTIVE SUMMARY}

This report tabulates the chemical analysis of the $3 \mathrm{H}, 2 \mathrm{H}$ and $2 \mathrm{~F}$ evaporator overhead samples including the inorganic, organic, and radionuclide species according the ETP WAC (rev.4). In addition, the physical properties including $\mathrm{pH}$, total suspended solids, and average particle size are listed for each sample. The report identifies all sample receipt dates, preparation methods, and analyses completed to accumulate these values. All values were found to be within the ETP WAC specifications for WWCT except for the ${ }^{137} \mathrm{Cs}$ concentration for the $2 \mathrm{~F}$ sample which was slightly above the limit $(\sim 5 \%)$. However, tank farm personnel sample each tank overhead for beta/gamma prior to transfer using a pulse height analyzer and these field readings were all well within limits. Additional actions will be taken to help understand the reason in the discrepancy of the field measurement versus laboratory analysis. 


\section{TABLE OF CONTENTS}

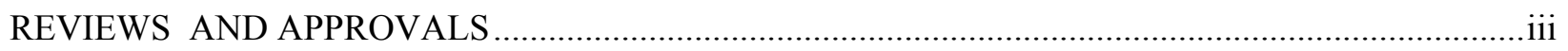

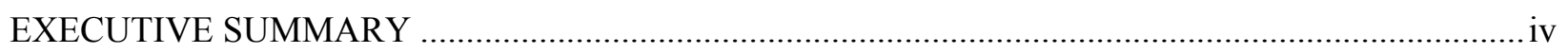

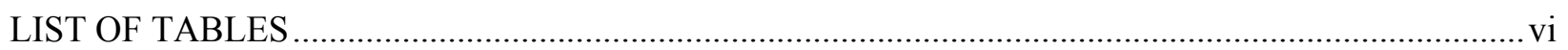

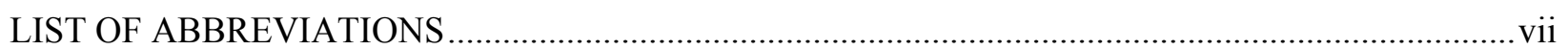

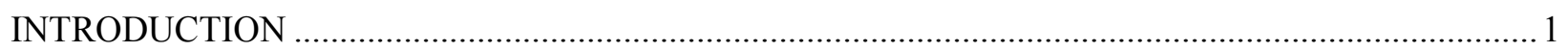

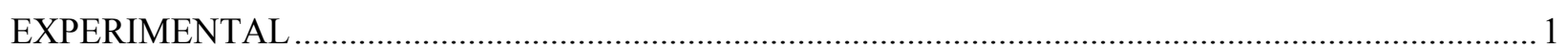

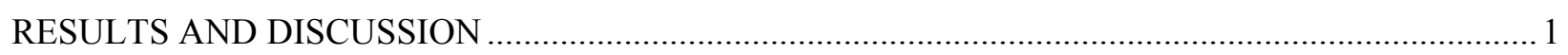

Table 1. Results of Chemical Analyses of Inorganic Species..................................................................2

Table 2. Results of Chemical Analyses of Organic Species ..................................................................... 3

Table 3. Results of Physical/Chemical Properties …............................................................................. 3

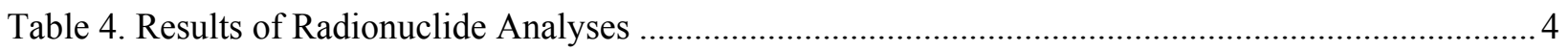

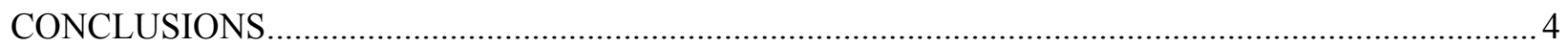

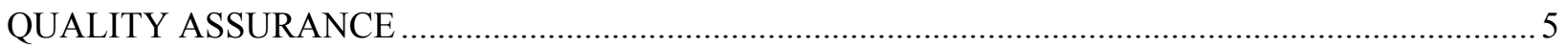

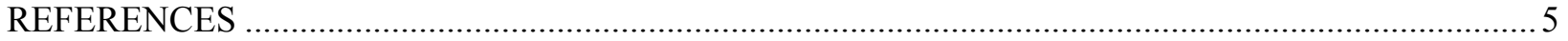




\section{LIST OF TABLES}

Table 1. Results of Chemical Analyses of Inorganic Species ................................................... 2

Table 2. Results of Chemical Analyses of Organic Species ................................................... 3

Table 3. Results of Physical/Chemical Properties .............................................................. 3

Table 4. Results of Radionuclide Analyses ............................................................................ 4 


\section{LIST OF ABBREVIATIONS}

$\begin{array}{ll}\text { ETP } & \text { Effluent Treatment Project } \\ \text { WAC } & \text { Waste Acceptance Criteria } \\ \text { ADS } & \text { Analytical Development Section } \\ \text { GC/MS } & \text { Gas Chromatography/Mass Spectroscopy } \\ \text { IC } & \text { Ion Chromatography } \\ \text { ICP-ES } & \text { Inductively Coupled Plasma-Emission Spectroscopy } \\ \text { AA } & \text { Atomic Absorption } \\ \text { CVAA } & \text { Cold Vapor Atomic Absorption } \\ \text { WWCT } & \text { Waste Water Collection Tanks } \\ \text { RCG } & \text { Radiological Control Guide }\end{array}$




\section{INTRODUCTION}

The Tank Farm has submitted the annual samples from $3 \mathrm{H}(8 / 16 / 2011), 2 \mathrm{H}(8 / 18 / 2011)$, and $2 \mathrm{~F}$ $(5 / 16 / 2011)$ Evaporator Overhead streams for characterization to verify compliance with the ETP WAC and to look for organic species.

\section{EXPERIMENTAL}

The annual evaporator overheads samples arrived at the Savannah River National laboratory between May 2011 and August 2011. Sample aliquots were measured and transferred to containers more suitable for transmittal to the Analytical Development Section (ADS). Since these samples were relatively low in activity, no dilution was required prior to submittal for analysis. In addition, clean de-ionized water was also submitted as blank samples to assess the background levels of the experiments.

A number of different analytical methods are used by ADS to determine the concentrations of various species in the samples. Both volatile and semivolatile organic species are determined using gas chromatography coupled with mass spectrometry (GC/MS). Ion chromatography (IC) is used to determine a number of anion species $\left(\mathrm{NO}_{3}^{-}, \mathrm{NO}_{2}^{-}, \mathrm{SO}_{4}{ }^{2-}, \mathrm{F}^{-}, \mathrm{Cl}^{-}, \mathrm{C}_{2} \mathrm{O}_{4}{ }^{2-}\right.$ and $\left.\mathrm{PO}_{4}{ }^{3-}\right)$ as well as the ammonium cation, $\mathrm{NH}_{4}{ }^{+}$. Inductively coupled plasma-emission spectrometry (ICP-ES) is used to determine a number of elemental species ( $\mathrm{Al}, \mathrm{Ag}, \mathrm{B}, \mathrm{Ba}, \mathrm{Be}, \mathrm{Cd}, \mathrm{Cr}, \mathrm{Fe}, \mathrm{Cu}, \mathrm{Mn}, \mathrm{Na}, \mathrm{Ni}, \mathrm{Pb}, \mathrm{Sb}$, and $\mathrm{Zn}$ ). A wet chemistry method is used to calculate the carbonate concentration. Atomic Absorption (AA) is used to determine the presence and concentration of As, Se and K. A cold vapor AA (CVAA) technique is used to measure the $\mathrm{Hg}$ concentration. Organic carbon was determined using a total organic carbon analyzer. Total suspended solids were measured gravimetrically. A TIM900 Titration System was used to measure sample $\mathrm{pH}$. A particle size analysis was not performed due to insufficient insoluble solids.

Radionuclide determinations were also made using a number of different methods. Gamma spectrometry was used where possible to determine many radionuclides $\left({ }^{137} \mathrm{Cs},{ }^{60} \mathrm{Co},{ }^{106} \mathrm{Ru},{ }^{126} \mathrm{Sn},{ }^{125} \mathrm{Sb},{ }^{154} \mathrm{Eu}\right)$. Gross alpha and non-volatile beta determinations were made by first removing the tritium and then using liquid scintillation counting. ${ }^{59} \mathrm{Ni},{ }^{63} \mathrm{Ni},{ }^{90} \mathrm{Sr},{ }^{79} \mathrm{Se},{ }^{14} \mathrm{C},{ }^{129} \mathrm{I}$, and ${ }^{241} \mathrm{Pu}$ were determined by chemical separations followed by beta counting. Tritium was determined by beta counting after separating the tritium by distillation. In preparation for this measurement, samples are evaporated down to dry smears and analyzed as such.

In addition to the radionuclide analysis performed by ADS, the tank farm also performs an initial sample screening using a pulse height analyzer.

\section{RESULTS AND DISCUSSION}

The results of the analyses provided in the tables below are for a single determination by Analytical Development (AD). For many species the concentration fell below the lower limit of detection. In these cases, AD reported the lower limit of detection preceded by " $<$ ".

Table 1 provides the measured values for inorganic species contaminants for the annual samples. Table 2 provides the measured values for the organic species contaminants. Table 3 provides the measured values for the physical and chemical properties of the annual samples. Table 4 provides the measured values for the radionuclide contaminants for the annual samples. The samples were submitted from the $2 \mathrm{~F}, 2 \mathrm{H}$, and $3 \mathrm{H}$ evaporator overheads, along with the limits given in the current revision of the ETP WAC and a 
reference sample to be analyzed in the same manner. Apart from the higher than WWCT feed limits shown in Table 4 for the ${ }^{137} \mathrm{Cs}$ observed in one evaporator overhead sample $(2 \mathrm{~F})$ which exceeds the deviation, ${ }^{2}$ no other species were found to be above the limits in the three evaporators for the annual samples.

Table 1. Results of Chemical Analyses of Inorganic Species

For Evaporator Overhead Samples for 2010

\begin{tabular}{|c|c|c|c|c|c|}
\hline Analyte & $\begin{array}{l}\text { Reference } \\
\text { Blank } \\
\text { Analysis } \\
(\mathbf{m g} / \mathbf{L})\end{array}$ & $\begin{array}{l}\text { 2F Evap. } \\
\text { Overheads } \\
\text { (mg/L) }\end{array}$ & $\begin{array}{l}\text { 2H Evap. } \\
\text { Overheads } \\
\text { (mg/L) }\end{array}$ & $\begin{array}{l}\text { 3H Evap. } \\
\text { Overheads } \\
\text { (mg/L) }\end{array}$ & $\begin{array}{l}\text { WWCT Feed } \\
\text { Acceptance Limits } \\
(\mathrm{mg} / \mathrm{L})\end{array}$ \\
\hline 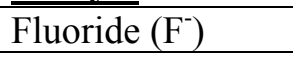 & $<1.00 \mathrm{E}+00$ & $<5.00 \mathrm{E}+00$ & $<1.00 \mathrm{E}+00$ & $<1.00 \mathrm{E}+00$ & $1.26 \mathrm{E}+01$ \\
\hline Chloride $\left(\mathrm{Cl}^{-}\right)$ & $<1.00 \mathrm{E}+00$ & $<5.00 \mathrm{E}+00$ & $<1.00 \mathrm{E}+00$ & $<1.00 \mathrm{E}+00$ & $3.00 \mathrm{E}+01$ \\
\hline Carbonate $\left(\mathrm{CO}_{3}{ }^{2-}\right)$ & $<2.50 \mathrm{E}+00$ & $2.00 \mathrm{E}+01$ & $2.00 \mathrm{E}+01$ & $1.50 \mathrm{E}+01$ & $1.12 \mathrm{E}+03$ \\
\hline Nitrite $\left(\mathrm{NO}_{2}^{-}\right)$ & $<1.00 \mathrm{E}+00$ & $<5.00 \mathrm{E}+00$ & $<1.00 \mathrm{E}+00$ & $<1.00 \mathrm{E}+00$ & $1.99 \mathrm{E}+02$ \\
\hline Nitrate $\left(\mathrm{NO}_{3}^{-}\right)$ & $<1.00 \mathrm{E}+00$ & $<5.00 \mathrm{E}+00$ & $<1.00 \mathrm{E}+00$ & $<1.00 \mathrm{E}+00$ & $3.40 \mathrm{E}+03$ \\
\hline Phosphate $\left(\mathrm{PO}_{4}{ }^{3-}\right)$ & $<1.00 \mathrm{E}+00$ & $<5.00 \mathrm{E}+00$ & $<1.00 \mathrm{E}+00$ & $<1.00 \mathrm{E}+00$ & $1.84 \mathrm{E}+01$ \\
\hline Sulfate $\left(\mathrm{SO}_{4}^{2-}\right)$ & $<1.00 \mathrm{E}+00$ & $<5.00 \mathrm{E}+00$ & $<1.00 \mathrm{E}+00$ & $<1.00 \mathrm{E}+00$ & $1.33 \mathrm{E}+02$ \\
\hline Oxalate $\left(\mathrm{C}_{2} \mathrm{O}_{4}{ }^{2-}\right)$ & $<1.00 \mathrm{E}+00$ & $<5.00 \mathrm{E}+00$ & $<1.00 \mathrm{E}+00$ & $<1.00 \mathrm{E}+00$ & $2.54 \mathrm{E}+02$ \\
\hline Silver (Ag) & N/A & $<2.90 \mathrm{E}-02$ & $<2.90 \mathrm{E}-02$ & $<2.90 \mathrm{E}-02$ & $7.82 \mathrm{E}+01$ \\
\hline Aluminum $(\mathrm{Al})$ & N/A & $<6.60 \mathrm{E}-02$ & $<6.60 \mathrm{E}-02$ & $<6.60 \mathrm{E}-02$ & $1.08 \mathrm{E}+03$ \\
\hline Arsenide (As) & $\mathrm{N} / \mathrm{A}$ & $<2.75 \mathrm{E}-02$ & $<2.75 \mathrm{E}-02$ & $<2.75 \mathrm{E}-02$ & $1.50 \mathrm{E}+00$ \\
\hline Boron (B) & $\mathrm{N} / \mathrm{A}$ & $<2.80 \mathrm{E}-02$ & $<2.80 \mathrm{E}-02$ & $<2.80 \mathrm{E}-02$ & $1.50 \mathrm{E}+01$ \\
\hline Barium $(\mathrm{Ba})$ & $\mathrm{N} / \mathrm{A}$ & $<1.30 \mathrm{E}-02$ & $<1.30 \mathrm{E}-02$ & $<1.30 \mathrm{E}-02$ & $5.77 \mathrm{E}+00$ \\
\hline Beryllium $(\mathrm{Be})$ & $\mathrm{N} / \mathrm{A}$ & $<2.00 \mathrm{E}-03$ & $<2.00 \mathrm{E}-03$ & $<2.00 \mathrm{E}-03$ & $2.00 \mathrm{E}-01$ \\
\hline Cadmium (Cd) & $\mathrm{N} / \mathrm{A}$ & $<1.30 \mathrm{E}-02$ & $<1.30 \mathrm{E}-02$ & $<1.30 \mathrm{E}-02$ & $2.58 \mathrm{E}+00$ \\
\hline Chromium (Cr) & N/A & $<2.00 \mathrm{E}-02$ & $<2.00 \mathrm{E}-02$ & $<2.00 \mathrm{E}-02$ & $8.40 \mathrm{E}+00$ \\
\hline Copper $(\mathrm{Cu})$ & N/A & $<1.30 \mathrm{E}-02$ & $<1.30 \mathrm{E}-02$ & $<1.30 \mathrm{E}-02$ & $9.00 \mathrm{E}+2$ \\
\hline Iron $(\mathrm{Fe})$ & $\mathrm{N} / \mathrm{A}$ & $<1.90 \mathrm{E}-02$ & $<1.90 \mathrm{E}-02$ & $<1.90 \mathrm{E}-02$ & $4.00 \mathrm{E}+02$ \\
\hline Mercury $(\mathrm{Hg})$ & $\mathrm{N} / \mathrm{A}$ & $<1.00 \mathrm{E}-02$ & $2.65 \mathrm{E}+00$ & $6.22 \mathrm{E}-02$ & $3.52 \mathrm{E}+01$ \\
\hline Manganese (Mn) & $\mathrm{N} / \mathrm{A}$ & $<4.00 \mathrm{E}-03$ & $<4.00 \mathrm{E}-03$ & $<4.00 \mathrm{E}-03$ & $9.00 \mathrm{E}+02$ \\
\hline Potassium $(\mathrm{K})$ & $\mathrm{N} / \mathrm{A}$ & $<1.50 \mathrm{E}-01$ & $<1.50 \mathrm{E}-01$ & $<1.50 \mathrm{E}-01$ & $\mathrm{~N} / \mathrm{A}$ \\
\hline Sodium $(\mathrm{Na})$ & N/A & $2.17 \mathrm{E}-01$ & $2.45 \mathrm{E}-01$ & $<1.06 \mathrm{E}-01$ & $\mathrm{~N} / \mathrm{A}$ \\
\hline Nickel (Ni) & $\mathrm{N} / \mathrm{A}$ & $<9.10 \mathrm{E}-02$ & $<9.10 \mathrm{E}-02$ & $<9.10 \mathrm{E}-02$ & $9.52 \mathrm{E}+01$ \\
\hline Lead $(\mathrm{Pb})$ & $\mathrm{N} / \mathrm{A}$ & $<1.43 \mathrm{E}-01$ & $<1.43 \mathrm{E}-01$ & $<1.43 \mathrm{E}-01$ & $3.71 \mathrm{E}+01$ \\
\hline Antimony (Sb) & $\mathrm{N} / \mathrm{A}$ & $<2.13 \mathrm{E}-01$ & $<2.13 \mathrm{E}-01$ & $<2.13 \mathrm{E}-01$ & $1.50 \mathrm{E}+00$ \\
\hline Selenium (Se) & $\mathrm{N} / \mathrm{A}$ & $<5.50 \mathrm{E}-02$ & $<5.50 \mathrm{E}-02$ & $<5.50 \mathrm{E}-02$ & $1.00 \mathrm{E}+00$ \\
\hline Zinc (Zn) & $\mathrm{N} / \mathrm{A}$ & $<1.30 \mathrm{E}-02$ & $<1.30 \mathrm{E}-02$ & $<1.30 \mathrm{E}-02$ & $5.92 \mathrm{E}+01$ \\
\hline Ammonia $\left(\mathrm{NH}_{3}\right)$ & N/A & $9.00 \mathrm{E}+00$ & $1.80 \mathrm{E}+01$ & $5.00 \mathrm{E}+00$ & $2.00 \mathrm{E}+01$ \\
\hline
\end{tabular}

N/A: Not Available

*3H is same as blank in both 2009 and 2010 samples 
Table 2. Results of Chemical Analyses of Organic Species

For Evaporator Overhead Samples for 2010

\begin{tabular}{|l|l|l|l|l|l|}
\hline & $\begin{array}{l}\text { Reference } \\
\text { Blank } \\
\text { Analysis } \\
\text { Analyte }\end{array}$ & $\begin{array}{l}\text { 2F Evap. } \\
\text { Overheads } \\
\text { (mg/L) }\end{array}$ & $\begin{array}{l}\text { 2H Evap. } \\
\text { Overheads } \\
\text { (mg/L) }\end{array}$ & $\begin{array}{l}\text { 3H Evap. } \\
\text { Overheads } \\
\text { (mg/L) }\end{array}$ & $\begin{array}{l}\text { WWCT Feed } \\
\text { Acceptance } \\
\text { Limits }\end{array}$ \\
\hline Pheng/L) & $<1.00 \mathrm{E}+01$ & $<1.00 \mathrm{E}+01$ & $<1.00 \mathrm{E}+01$ & $<1.00 \mathrm{E}+01$ & $3.85 \mathrm{E}+02$ \\
\hline Benzene & $<1.00 \mathrm{E}+00$ & $<1.00 \mathrm{E}+00$ & $<1.00 \mathrm{E}+00$ & $<1.00 \mathrm{E}+00$ & $3.79 \mathrm{E}+02$ \\
\hline Toluene & $<1.00 \mathrm{E}+00$ & $<1.00 \mathrm{E}+00$ & $<1.00 \mathrm{E}+00$ & $<1.00 \mathrm{E}+00$ & $3.85 \mathrm{E}+02$ \\
\hline Trichloroethene & $<1.00 \mathrm{E}+00$ & $<1.00 \mathrm{E}+00$ & $<1.00 \mathrm{E}+00$ & $<1.00 \mathrm{E}+00$ & $2.63 \mathrm{E}+00$ \\
\hline $\begin{array}{l}\text { Tetrachloroethene } / \\
\text { Perchloroethene }(\mathrm{PCE})\end{array}$ & $<1.00 \mathrm{E}+00$ & $<1.00 \mathrm{E}+00$ & $<1.00 \mathrm{E}+00$ & $<1.00 \mathrm{E}+00$ & $1.92 \mathrm{E}+00$ \\
\hline PCB & $<1.00 \mathrm{E}-01$ & $<1.00 \mathrm{E}-01$ & $<1.00 \mathrm{E}-01$ & $<1.00 \mathrm{E}-01$ & $9.04 \mathrm{E}-01$ \\
\hline Tetraphenlyborate (TPB) & $<5.00 \mathrm{E}+00$ & $<5.00 \mathrm{E}+00$ & $<5.00 \mathrm{E}+00$ & $<5.00 \mathrm{E}+00$ & N/A \\
\hline TOC & $1.00 \mathrm{E}+00$ & $3.00 \mathrm{E}+00$ & $8.00 \mathrm{E}+00$ & $1.00 \mathrm{E}+00$ & $3.85 \mathrm{E}+02$ \\
\hline
\end{tabular}

N/A: No TPB is allowed in these samples

ND: Not Detected

Table 3. Results of Physical/Chemical Properties

For Evaporator Overhead Samples for 2010

\begin{tabular}{|l|l|l|l|l|l|}
\hline Analyte & $\begin{array}{l}\text { Reference } \\
\text { Blank } \\
\text { Analysis }\end{array}$ & $\begin{array}{l}\text { 2F Evap. } \\
\text { Overheads }\end{array}$ & $\begin{array}{l}\text { 2H Evap. } \\
\text { Overheads }\end{array}$ & $\begin{array}{l}\text { WH Evap. } \\
\text { Overheads }\end{array}$ & $\begin{array}{l}\text { Acceptance } \\
\text { Limits }\end{array}$ \\
\hline Total Suspended Solids (TSS) & $\mathrm{N} / \mathrm{A}$ & $<0.1 \mathrm{wt} \%^{\alpha}$ & $<0.1 \mathrm{wt} \% \%^{\chi}$ & $<0.1 \mathrm{wt}^{\alpha} \%^{\chi}$ & $1.00 \mathrm{E}+02$ \\
\hline Particle Size (microns) & $\mathrm{N} / \mathrm{A}$ & $\mathrm{ND}$ & $\mathrm{ND}$ & $\mathrm{ND}$ & $350 \mathrm{microns}$ \\
\hline $\mathrm{pH}$ (no units) & 6.54 & 9.39 & 9.97 & 9.42 & 1 to 12.5 \\
\hline
\end{tabular}

${ }^{\chi}$ Low total suspended solids, so the particle size distribution was not evaluated.

$\delta$ Not Detected: insufficient particles for data. 
Table 4. Results of Radionuclide Analyses

For Evaporator Overhead Samples for 2010

\begin{tabular}{|l|l|l|l|l|l|}
\hline Analyte & $\begin{array}{l}\text { Reference } \\
\text { Blank Analysis } \\
\mathbf{( d p m} / \mathbf{m L})\end{array}$ & $\begin{array}{l}\text { 2F Evap. } \\
\text { Overheads } \\
\text { (dpm/mL) }\end{array}$ & $\begin{array}{l}\text { 2H Evap. } \\
\text { Overheads } \\
\text { (dpm/mL) }\end{array}$ & $\begin{array}{l}\text { 3H Evap. } \\
\text { Overheads } \\
\text { (dpm/mL) }\end{array}$ & $\begin{array}{l}\text { WWCT Feed } \\
\text { Acceptance } \\
\text { Limits } \\
\text { (dpm/mL) }\end{array}$ \\
\hline Alpha & N/A & $<9.23 \mathrm{E}+00$ & $<4.75 \mathrm{E}+00$ & $<8.47 \mathrm{E}+00$ & $2.00 \mathrm{E}+01$ \\
\hline Beta/Gamma & N/A & $8.38 \mathrm{E}+02^{\alpha}$ & $2.34 \mathrm{E}+01$ & $2.05 \mathrm{E}+02$ & $1.30 \mathrm{E}+03$ \\
\hline${ }^{90} \mathrm{Sr}$ & N/A & $<1.62 \mathrm{E}+01$ & $<1.63 \mathrm{E}+01$ & $<1.64 \mathrm{E}+01$ & $1.76 \mathrm{E}+02$ \\
\hline${ }^{3} \mathrm{H}$ & N/A & $1.35 \mathrm{E}+04$ & $5.28 \mathrm{E}+02$ & $6.75 \mathrm{E}+03$ & $1.20 \mathrm{E}+05$ \\
\hline${ }^{14} \mathrm{C}$ & N/A & $<7.34 \mathrm{E}+00$ & $<7.34 \mathrm{E}+00$ & $<7.34 \mathrm{E}+00$ & $1.91 \mathrm{E}+03$ \\
\hline${ }^{63} \mathrm{Ni}$ & N/A & $<1.32 \mathrm{E}+01$ & $<1.87 \mathrm{E}+01$ & $<1.14 \mathrm{E}+01$ & $1.91 \mathrm{E}+03$ \\
\hline${ }^{60} \mathrm{Co}$ & N/A & $<2.09 \mathrm{E}+00$ & $<4.58 \mathrm{E}+00$ & $<4.89 \mathrm{E}+00$ & $1.30 \mathrm{E}+01$ \\
\hline${ }^{99} \mathrm{Tc}$ & N/A & $<9.26 \mathrm{E}+00$ & $<9.09 \mathrm{E}+00$ & $<9.11 \mathrm{E}+00$ & $2.50 \mathrm{E}+03$ \\
\hline${ }^{106} \mathrm{Ru}$ & N/A & $<1.56 \mathrm{E}+01$ & $<2.54 \mathrm{E}+01$ & $<2.96 \mathrm{E}+01$ & $7.92 \mathrm{E}+02$ \\
\hline${ }^{126} \mathrm{Sn}$ & N/A & $<9.98 \mathrm{E}+00$ & $<4.63 \mathrm{E}+00$ & $<6.16 \mathrm{E}+00$ & $9.38 \mathrm{E}+01$ \\
\hline${ }^{125} \mathrm{Sb}$ & N/A & $<4.24 \mathrm{E}+00$ & $<8.36 \mathrm{E}+00$ & $<1.36 \mathrm{E}+01$ & $4.32 \mathrm{E}+02$ \\
\hline${ }^{129} \mathrm{I}$ & N/A & $<4.49 \mathrm{E}-01$ & $<5.77 \mathrm{E}-01$ & $<6.06 \mathrm{E}-01$ & $1.00 \mathrm{E}+00$ \\
\hline${ }^{137} \mathrm{Cs}$ & N/A & $1.05 \mathrm{E}+03^{\alpha}$ & $1.76 \mathrm{E}+01$ & $2.26 \mathrm{E}+02$ & $1.00 \mathrm{E}+03^{\gamma}$ \\
\hline${ }^{154} \mathrm{Eu}$ & N/A & $<3.81 \mathrm{E}+00$ & $<3.26 \mathrm{E}+00$ & $<4.32 \mathrm{E}+00$ & $2.50 \mathrm{E}+01$ \\
\hline${ }^{233} \mathrm{U}$ & N/A & $<6.42 \mathrm{E}-01$ & $<6.42 \mathrm{E}-01$ & $<6.42 \mathrm{E}-01$ & $6.60 \mathrm{E}+01$ \\
\hline${ }^{235} \mathrm{U}$ & N/A & $<9.60 \mathrm{E}-05$ & $<9.60 \mathrm{E}-05$ & $<9.60 \mathrm{E}-05$ & $6.09 \mathrm{E}-01$ \\
\hline${ }^{238} \mathrm{U}$ & N/A & $<2.24 \mathrm{E}-05$ & $<2.24 \mathrm{E}-05$ & $<2.24 \mathrm{E}-05$ & N/A \\
\hline${ }^{238} \mathrm{Pu}$ & N/A & $<5.44 \mathrm{E}-01$ & $<7.09 \mathrm{E}-01$ & $<6.70 \mathrm{E}-01$ & N/A \\
\hline${ }^{239 / 240} \mathrm{Pu}$ & N/A & $<6.33 \mathrm{E}-01$ & $<5.83 \mathrm{E}-01$ & $<1.03 \mathrm{E}+00$ & N/A \\
\hline${ }^{241} \mathrm{Pu}$ & N/A & $<1.71 \mathrm{E}+01$ & $<1.71 \mathrm{E}+01$ & $<1.71 \mathrm{E}+01$ & $2.64 \mathrm{E}+02$ \\
\hline${ }^{237} \mathrm{~Np}$ & N/A & $<3.13 \mathrm{E}-02$ & $<3.13 \mathrm{E}-02$ & $<3.13 \mathrm{E}-02$ & $1.30 \mathrm{E}-01$ \\
\hline $\mathrm{RCG}$ & N/A & $2.56 \mathrm{E}-02$ & $1.80 \mathrm{E}-03$ & $7.01 \mathrm{E}-03$ & $2.57 \mathrm{E}-02^{\gamma}$ \\
\hline${ }^{*} \mathrm{Rad}$ & N $/ \mathrm{A}$ & & \\
\hline
\end{tabular}

*Radiological Control Guide: \# RCG $=\left(0.000102\left[{ }^{60} \mathrm{Co}\right]+0.00000875\left[{ }^{106} \mathrm{Ru}\right]+0.0000178\left[{ }^{125} \mathrm{Sb}\right]\right.$ $\left.+0.0000234\left[{ }^{137} \mathrm{Cs}\right]+0.0000508\left[{ }^{154} \mathrm{Eu}\right]+0.0000819\left[{ }^{126} \mathrm{Sn}\right]\right)$ where the concentrations are given in $\mathrm{dpm} / \mathrm{mL}$. Note the results given here assume that any radionuclide concentration results that came back less than detectable are considered to be at the lower limit of detection.

${ }^{\alpha}$ Tank farm PHA shows an average ${ }^{137} \mathrm{Cs}$ concentration of $540 \mathrm{dpm} / \mathrm{mL}$ with a max concentration of 603 $\mathrm{dpm} / \mathrm{mL} .^{3}$

${ }^{\gamma}$ Deviation to WAC allows values to be $1000 \mathrm{dpm}$ for ${ }^{137} \mathrm{Cs}$ and $2.57 \mathrm{E}-02$ for the RCG value. This is higher than the current WWCT limits of $328 \mathrm{dpm}$ for ${ }^{137} \mathrm{Cs}$ and $7.69 \mathrm{E}-03$ for the RCG value. ${ }^{2}$

N/A: Not Available

\section{CONCLUSIONS}

All the overheads samples were found to be in compliance with the Effluent Treatment Project WAC with the exception of the ${ }^{137} \mathrm{Cs}$ value for the $2 \mathrm{~F}$ evaporator overheads. The ${ }^{137} \mathrm{Cs}$ value for the $2 \mathrm{~F}$ evaporator sample exceeds the current WAC deviation by $5 \%{ }^{2}$ This deviation allows for elevated limits of ${ }^{137} \mathrm{Cs}$ covering the excess beta/gamma in the samples and also increasing the RCG limits. The ${ }^{137} \mathrm{Cs}$ and RCG values are shown in Table 4. Tank farm Operations personnel sample each $2 \mathrm{~F}$ evaporator overheads tank and measure the beta/gamma concentration using a pulse height analyzer prior to transfer to ETP. The $2 \mathrm{~F}$ system engineer reviewed the PHA sample results obtained during the period of time that the $2 \mathrm{~F}$ evaporator was sampled for the annual WAC analysis and all results during this period of time were in the range of $500-600 \mathrm{~d} / \mathrm{m} / \mathrm{ml}^{3}$. Additional actions will be taken to determine if the reason for this discrepancy can be identified. 


\section{QUALITY ASSURANCE}

Results of the analyses described in this report are documented in SRNL-NB-2010-00013.

\section{REFERENCES}

1. "F/H Effluent Treatment Facility Waste Acceptance Criteria," X-SD-H-00009, Revision 5, August 4, 20011.

2. "Request for Deviation to ETP Waste Acceptance Criteria," ETP-RFD-2011-00008, Expires August 2, 2012.

3. Personal email communication with Paul Rogerson. Paul keeps a copy of the operator's log for PHA sample analysis. 